\title{
Studies on the Antidotal Action of Drugs
}

\section{Part 1 Vitamin C and Its Antidotal Effect against Alcoholic and Nicotine Poisoning}

\author{
by \\ Toyoyuki TAMURA,* Hiroshi INOUE, * Takashi IIDA* \\ and Hiromitsu $O N O^{*}$
}

Vitamin $\mathrm{C}$ in its various preparations is one of the most commonly administered drugs in dentistry. In connection with many researches related to the poisoning of many pharmaceuticals, research endeavors are also active in the antidotal action of these drugs.

TAMURA, one of the present authors, published his experimental studies on the elimination of an injurious by-effect of promine $[1,2]$ and also those dealing with leucine against caffeine[3], substances having antidotal effects on morphine and nicotine [4] and anti-alcoholic agent [5].

Although the possibility of vitamin $\mathrm{C}$ poisoning has drawn the attention of medical and dental profession for a long time, almost nothing is known about its effect when administered conjointly with some form of amino acid.

In the present report, the authors are concerned with the antidotal mechanism of vitamin $\mathrm{C}$ and glucose-cysteine against acetaldehyde responsible for the alcoholism and nicotine, a potent factor in the nicotinism.

\section{Material and Method}

By way of experimental animal, male mice of DD strain weighing around 20 grams each were selectively used.

Two kinds of antidotal reagents were prepared: one was a preparation of vitamin $\mathrm{C}$ alone where $400 \mathrm{mg}$ (Pharmacopeia japonica) was dissolved in $10 \mathrm{ml}$ pure water and the other contained $50 \mathrm{mg}$ glucose-cysteine and $32.5 \mathrm{mg}$ vitamin $\mathrm{C}$, the latter being referred to as $\mathrm{CC}$ reagent here. The $\mathrm{CC}$ reagent was thoroughly crushed by the pestle and mortar and $10 \mathrm{ml}$ pure water was added to a proportion of 1 gram.

Similarly, two toxic agents were prepared as follows. One was a 10 -time aquous solution of acetaldehyde (Pharmacopeia japonica) and the other was $60 \mathrm{ml}$ physiologic saline in which 17 cigarettes of a common Japanese brand (sold under the tradename of Hilite) were briefly immersed to obtain a nicotine solution.

\section{Experimental Results}

1. Antidotal action against acetaldehyde.

The antidotal actions of vitamin $\mathrm{C}$ and $\mathrm{CC}$ reagent were respectively determined

* 田村豊幸, 井上博, 飯田高史, 大野洋光: Department of Pharmacology, Nihon Univ. School of Dentistry (Director: Mikio Sato) 
by changing concentrations of the latter. Table 1 below summarizes the result under this heading.

Table 1. Antidotal actions of vitamin $\mathrm{C}$ and $\mathrm{CC}$ reagent against the toxicity of acetaldehyde

\begin{tabular}{cclc}
\hline \hline Reagent & Acetaldehyde & \multicolumn{1}{c}{ Manner given } & $\begin{array}{c}\text { Death rate } \\
(\%)\end{array}$ \\
\hline Vitamin C alone & & Given 30 minutes earlier & 60 \\
$40 \mathrm{mg} / \mathrm{kg}$ & $10 \mathrm{ml} / \mathrm{kg}$ & Acetaldehyde and CC together & 40 \\
Glucose-cysteine added & & Given 30 minutes earlier & 10 \\
$1 \mathrm{~g} / \mathrm{kg}$ & & Given 30 minutes earlier & 0 \\
$10 \mathrm{mg} / \mathrm{kg}$ & $10 \mathrm{ml} / \mathrm{kg}$ & Given 30 minutes earlier & 0 \\
$100 \mathrm{mg} / \mathrm{kg}$ & $10 \mathrm{ml} / \mathrm{kg}$ & Given 30 minutes earlier & 20 \\
$1 \mathrm{~g} / \mathrm{kg}$ & $10 \mathrm{ml} / \mathrm{kg}$ & & \\
$60 \mathrm{mg} / \mathrm{kg}$ & $10 \mathrm{ml} / \mathrm{kg}$ & &
\end{tabular}

\section{Antidotal action against nicotine.}

The nicotine solution as described in the foregoing section was injected into the experimental mice and the antidotal action of vitamin $\mathrm{C}$ either singly or conjointly with glucose-cysteine was determined (Table 2).

The average length of survival of a mouse after being injected with a nicotine solution was 13.0 minutes.

Table 2. Antidotal actions of vitamin $\mathrm{C}$ and $\mathrm{CC}$ reagent against the toxicity of nicotine

\begin{tabular}{|c|c|c|c|}
\hline Reagent & $\begin{array}{l}\text { Nicotine } \\
\text { (LD 50) }\end{array}$ & Manner given & $\begin{array}{l}\text { Length of } \\
\text { survival } \\
\text { (Mean) }\end{array}$ \\
\hline \multicolumn{4}{|l|}{ Vitamin $\mathrm{C}$ alone } \\
\hline $400 \mathrm{mg} / \mathrm{kg}$ & $31 \mathrm{ml} / \mathrm{kg}$ & Given 30 minutes earlier & $16.0 \mathrm{~min}$ \\
\hline \multicolumn{4}{|c|}{ Glucose-cysteine added } \\
\hline $600 \mathrm{mg} / \mathrm{kg}$ & $31 \mathrm{ml} / \mathrm{kg}$ & Given 30 minutes earlier & $10.6 \mathrm{~min}$ \\
\hline $1 \mathrm{~g} / \mathrm{kg}$ & $31 \mathrm{ml} / \mathrm{kg}$ & Given 3 days consecutively & $20.0 \mathrm{~min}$ \\
\hline $1 \mathrm{~g} / \mathrm{kg}$ & $31 \mathrm{ml} / \mathrm{kg}$ & Given 30 minutes earlier & $34.0 \mathrm{~min}$ \\
\hline
\end{tabular}

\section{Conclusions}

As a result of our research to determine the effect of a conjoint use of glucosecysteine in connection with vitamin $\mathrm{C}$, the following conclusions were arrived at.

1. When used conjointly with glucose-cysteine, vitamine $\mathrm{C}$ will definitely increase its antidotal action against the toxicity of acetaldehyde which is chiefly responsible for the alcoholism.

2. Similarly, a conjoint application of glucose-cysteine and vitamin $\mathrm{C}$ has a pronounced increase in its antidotal action against the toxicity of nicotine. 


\section{References}

[1] Tamura, T.: A pharmacological study on the elimination of an injurious by-effect of promine, Lepra J., 22: 142-146, (1953).

[2] Ditto: A study on the elimination of by-effect of promine by the use of vitamin $\mathrm{B}_{12}$, follic acid and liver extract, Shika-Geppo, 30: 79-83, (1956).

[3] Ditto: Certain antidotal action of amino acids against caffeine, J. Kurume Med. Col., 20: 17571760, (1957).

[4] Ditto: Experimental pharmacological inquiries into a new anti-nicotine and anti-morphine drug, J. Nihon U. Sch. Dent., 3: 119-123, (1961).

[5] Ditto: Observations on the anti-toxic property of Au-610 drug on nicotinism and alcoholism, J. Nihon U. Sch. Dent., 5: 187-195, (1963). 